\title{
The Presence of the Ghaznavids' Court Glory: An Analysis of Lashkari-Bazar in Light of the Sociopolitical Order Through Historical and Panegyric Materials
}

\author{
Shangxiner $\mathrm{Li}^{1, \mathrm{a}}$ \\ ${ }^{1}$ School of the Arts, SOAS, University of London, London, WC1H OXG, United Kingdom \\ ${ }^{a}$ Email: shangxinerli@gmail.com
}

\begin{abstract}
During the tenth to twelfth centuries in the central and eastern Islamic areas, largely today's Afghanistan, the military Turks established a Sunni dynasty called the Ghaznavids. It was an era of great glory and constant tension in the Islamic world, defined as the medieval Islamic period, with the Ghaznavids' reformed political structure, enormous military exploitation, regular seasonal migration, lavish court ceremonies and flourishing cultural scenes. This article will examine architectural plans and fresco paintings in the audience hall of Lashkari-Bazar to illustrate the presence of the Ghaznavids' court glory in terms of the socio-political order.
\end{abstract}

Keywords: the Ghaznavids, the Lashkari-Bazar, Mas'ud, Bust, fresco

\section{INTRODUCTION}

During the tenth to twelfth centuries in the central and eastern Islamic areas, largely today's Afghanistan, the military Turks established a Sunni dynasty called the Ghaznavids[1]. The dynasty set the capital as Ghazni and pushed the boundary forward eastwards into India and westward of east Iran. The first ruler, Sebuktigin was a Samanid military commander of Turkish slave origin. His son, Mahmud, acclaimed as the first sultan, expanded the empire and adopted an elaborate administrative and cultural plan from the Persian- influenced Samanids[2]. Officials from different regions came to the Ghazanavids' court for Mahmud's appreciation of intellectual men. Mahmud's son Mas'ud took the role of ruler and continued Mahmud's tradition. The dynasty has also been admired for its Islamic culture, for example, the gardening scenes and ceremonies recorded in the panegyrics at the time[3]. This was an era of great glory and constant tension in the Islamic world, defined as the medieval Islamic period, with Ghaznavid's reformed political structure, enormous military exploitation, regular seasonal migration, lavish court ceremonies, and flourishing cultural scenes. This article will examine architectural plans and fresco paintings in the audience hall of Lashkari-Bazar, to illustrate the presence of the
Ghaznavids' court glory in terms of the socio-political order. Lashkari-Bazar was an archetype of royal glory. The complex and the frescos bear eternal witness to the Ghanavids' dynastic past. This essay will use historical and panegyric materials to support the thesis.

\subsection{The socio-political factors of the Ghaznavids' court that has influenced the construction of Lashkari-Bazar}

\subsubsection{The Persian Culture}

There are three major socio-political factors that influenced the Ghaznavids' palatial construction seen in Lashkari Bazar. The first is that the court had been influenced by Persian culture. The Ghaznavids adopted the Persian administrative model and cultural paradigm from the Samanids. During Mahmud' s reign, an accounting office and a communications department were set up[4]. The latter took charge of espionage activity, which was important at the time because the empire spanned widely and internal divisions were constant[5]. Other than that, the Sultan also followed the Samanids court practice to congregate intelligent men to the royal centre [6]. The court, which intended to attract able men, attracted people from the Persian and Islamic world, 
including famous poets, musicians, scientists, and political officials, to surround the Sultan at the court of employment [7]. The exertion of the Sultan' s presence in the political discourse and the Sultan' s congregational powers were demonstrations of the sociopolitical order during the Ghaznavids' rule. They would be projected in the palatial structure and fresco paintings at Lashkari-Bazar, the subject of which I will illustrate in more detail in later passages.

\subsubsection{The itinerancy}

The second socio-political factor is that the Ghaznavids promoted itinerancy for different purposes as a model to impose dynastic power (fig 1) [8]. There were five main reasons for the year-round tour by the Sultan and high officials: military intention, seasonal migration, Islamic festival celebration, tax raises and political propaganda. In the case of Lashkari-Bazar in Bust, five causes all contributed to the architectural complex [9]. The location of Bust served as a transportation spot on the route towards the south-west. The route contributed to ten of a total of forty-eight journeys made by Sultan Mahmud and his son Mas' ud (fig 2) [10]. This shows the geopolitical importance of Bust, that it not only served as a military destination, but also as royal winter accommodation. During wintertime, the average temperature in Ghazni was below zero. Thus, the Sultan moved southward to cities such as Bust, Balkh, Nishapur, and Herat to avoid the harsh climate [11]. During the Sultan' s stay, he would give parties at the court and go on processions to be welcomed by the townspeople. The palatial plan and frescoed theme in Lashkari-Bazar indicate such factors. Although there was no direct evidence to suggest tax-raising activity in Bust, the economic intention was underpinned by the political promotion of the tour. Sultan Mas' ud was recorded acting on an Achaemenid tradition of exchanging valuable gifts with the locals during welcome ceremonies [12]. The locals would scatter money and sweets during the Sultan' s procession, and the Sultan would offer money to the poor people in the city in return. This ceremonial habit influenced the design of the axial palatial plan and the cheerful-sprite wall paintings of Lashkari-Bazar.

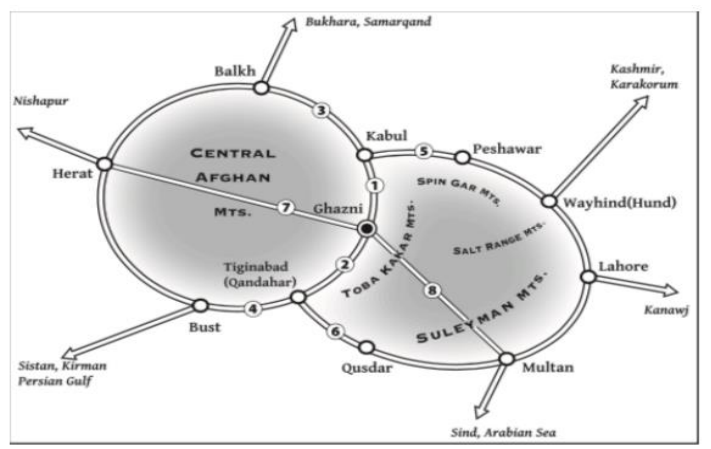

Fig 1. The 'figure-eight' road network of the Sultan 's early travels. In David Durand Guedy, TurkoMongol rulers, cities and city life. Leiden: Brill, 2013. 81 , plate 2 .

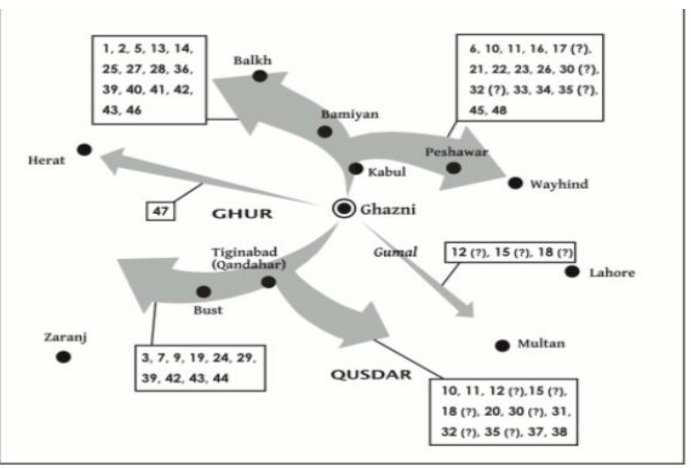

Figure 2. Directions of the Ghaznavid Sultan's travels. Each route' $s$ index number has been concluded into the square. For example, 10 routes were dedicated to the direction of Bust. In David Durand-Guedy., TurkoMongol rulers, Cities and City Life. Leiden: Brill, 2013. 81 , plate 3 .

\subsubsection{The panegyrics}

The third factor is the court appreciation of the panegyrics that drew many intellectual literary figures at the time to the Ghaznavids for work. Panegyrics were both historical records and a form of cultural activity at the court. During Sultan Mahmud's and Mas'ud's reign, great literary works of Islamic history were produced by talented authors such as Firdausi, Bayhaqi, Nizam alMulk and many others [13]. The documentation of historical events, together with contemporary happenings recorded by poets, was a way of articulating the royal power in both a spatial and temporal sense. The role of Ghaznavid panegyrics was to legitimize the coexistent situation of the Persian and Islamic populations, to provide criteria for the government to depict the Sultan as a just king and to celebrate the splendour of the Ghaznavids' [14]. Considering the synthetic attributes of Ghaznavid culture, the Sultan prompted poet writing as a way to legitimate power. The panegyrics not only exerted the Ghaznavids' contemporary taste into the literary paradigm, but also linked the court' s presence with its Persian past to suggest continuity [15]. Through written records, the Ghaznavid Sultan attempted to eternalize their reign. Dynasties may change in history, but the glorious presence of the Ghaznavids' rule was exemplified by royal ceremonies and would stay permanent in the panegyrics produced by court authors. 


\section{LASHKARI-BAZAR}

\subsection{Plan of the palatial complex}

Other than the panegyrics, the construction of palaces and fresco scenes in Lashkari-Bazar also reflected the Sultan' s ambition to be enduring. Built between the 10th and 12th centuries, Lashkari-Bazar lies along the east bank of the Hilmand River in the city of Bust (fig 3). The city took advantage of its location and served as a transportation point for business travelers, a military stronghold for the army, and the Sultan's winter palace. The enclosed palatial complex had thick walls and was organized in a processional axis. The overall immense scale, the display of palatial buildings, the adoption of the four-iwan plan, the painted audience hall, and decorations using marble, brick and stucco all suggest a royal ceremonial feature [16]. The famous Southern Palace is situated at the end of the bazaar, with a cardinal orientation by the riverbank (fig 4). The entrance of the two-storey façade may implicate the Ctesiphon gate, which has a Persian inference. The fortified walls at the cliff of the riverbank suggest a state of military defense. The guards used to stand by in the forecourt to safeguard the royal participants walking into the focal point of the axial architectural structure, which was marked by four large iwan halls [17]. The principal iwan, which is larger and higher, has a directional function and is at the north of the court, directing the processional viewer to the throne room at the back of the iwan hall. This is a reception room for audiences to feast, overlooking the Hilmand River, which indicates a ceremonial function [18].

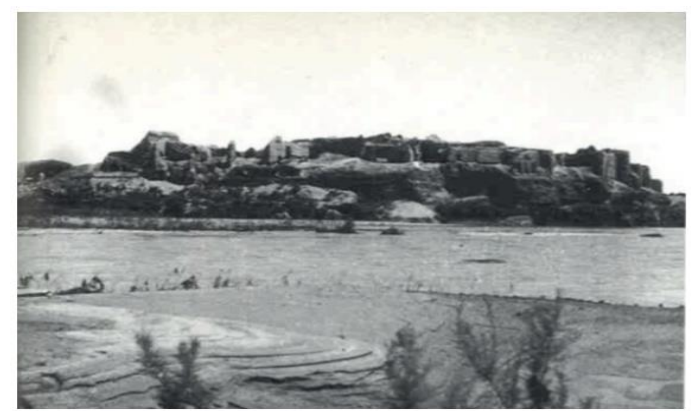

Fig 3. The palace complex viewed from the north side overlooking the Hilmand River. In Sourdel-Thomine,

Janine., Lashkari Bazar: une résidence royale ghaznévide. Paris: C. Klincksieck, 1963-68. Planche 48.

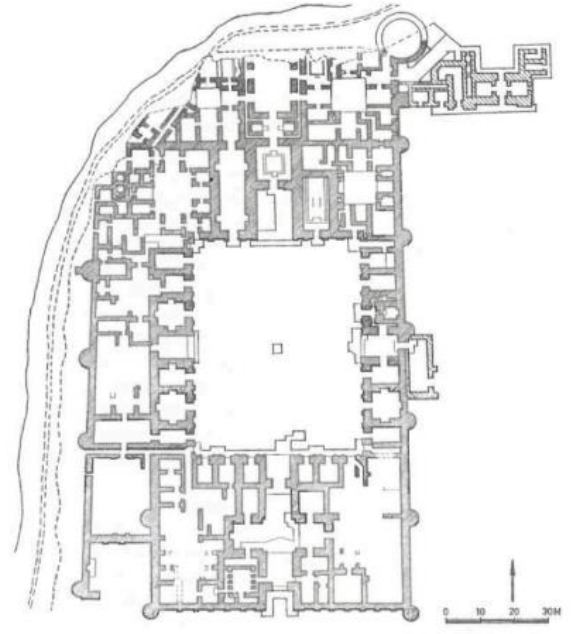

Fig 4. Lashkar-i Bazar. South palace plan. In Hilenbrand, Carole., Bosworth, Clifford., Edmund., The Sultan's Turret: Studies in Persian and Turkish Culture. Leiden: Brill, 2000. 148.

In fact, the river was a common element in palatial structures in the medieval Islamic world. Back to the time of Baghdad, the Caliph used to row a boat in the river to hold a drinking ceremony in the garden [19]. This Islamic tradition was also manifested by a Large River Pavilion situated in the north of the Centre Palace by the river. The pavilion is functioned as a viewing platform, with access to the riverside to hold elaborate gatherings [20]. The adjacent Centre Palace is a compact building with four equal divisions, divided by an elongated axial passage (fig 5). The central courtyard and the long access may imply a court ceremonial intention, which is reinforced by evidence that the architecture has an entrance to a garden. The garden scene was a major theme appraised by the panegyrics during that era. The connotations of the royal garden gatherings imply a sense of prosperity, which was ensured by the Sultan' s military conquests, thus, in turn legitimize the Sultan's rule [21]. 


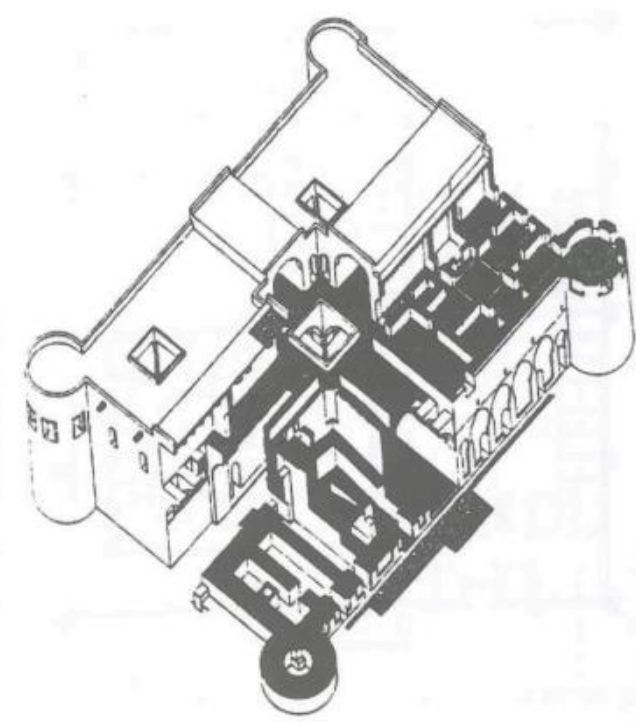

Fig 5. Lashkar-i Bazar. Central palace plan. In Hilenbrand, Carole., Bosworth, Clifford Edmund., The Sultan's Turret: Studies in Persian and Turkish Culture. Leiden: Brill, 2000. 149.

Archaeological evidence has been found to determine that the first floor of the Central Palace was not for accommodation purposes and neither accessible to the second story where royal residents used to live [22]. The security reason behind the design may well indicate the socio-political status of the era, in which the empire was constantly requiring military conquer. There is a North Palace in the north and a bazar adjacent to a mosque in the south (fig 6). The building complex is river-oriented and overall axial, which indicates the function of a ceremonial procession, a regular activity conducted by Sultan Mahmud and Mas' ud according to written records (fig 7).

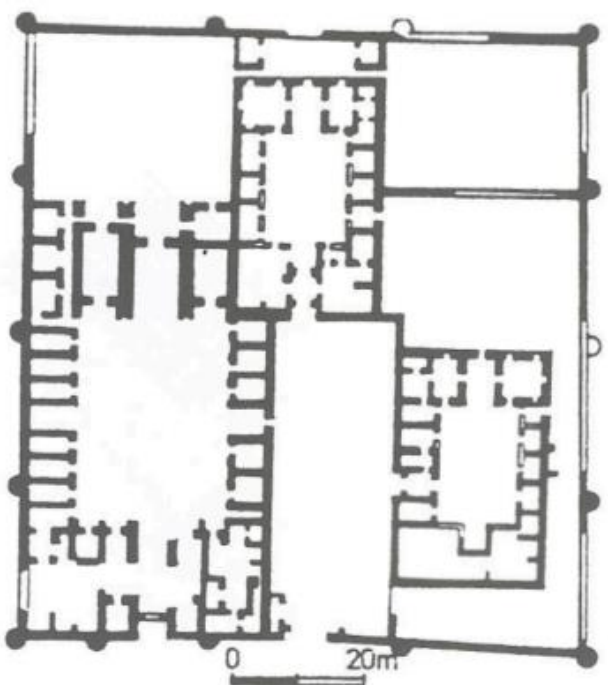

Fig 6. Lashkar-i Bazar. North Palace plan. In Hilenbrand, Carole., Bosworth, Clifford Edmund. The Sultan's Turret: Studies in Persian and Turkish Culture. Leiden: Brill, 2000. 150.

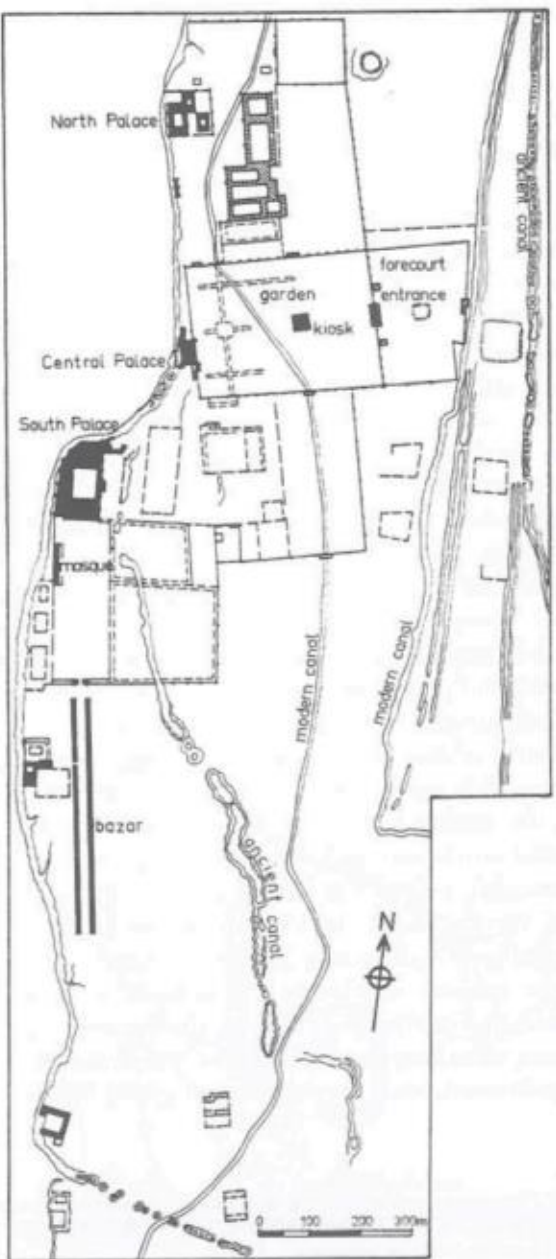

Fig 7. Lashkar-i Bazar. Site plan. In Hilenbrand, Carole., Bosworth, Clifford Edmund. The Sultan's Turret: Studies in Persian and Turkish Culture. Leiden: Brill, 2000. 151.

\subsection{Brick decoration and the wall fresco}

Lashkari-Bazar was constructed mainly of mud brick. But some other decorative materials have been found at archaeological sites. For example, in the South Palace, a wall was filled with baked brick to constitute decorative schemes in geometric and vegetal forms to intensify the lavishness of the royal court' s glory [23]. At the back of the principal iwan-hall, a large area of geometric patterns composed of bricks and stucco was found. The foremost archaeological findings in the palatial site are wall frescos depicting forty-four Turkish guards in the throne room where the Sultan used to greet the audience during reception ceremonies (fig 8) [25]. The custom was that Sultan Mahmud would enthrone himself in the ceremonies with thousands of bodyguards to accompany him. Thus, the image is a permanent representation of the Sultan' s royal celebration activities. The size of the guards on three walls of the hall interior is just a little shorter than a real figure. Formally, they are frontally presented, with faces shown in three-quarter view and feet 
standing in profile (fig 9). The guard figures are dressed in long decorated robes, with belts and jeweled appendages hung at the waist. Some figures are shown with halos, and some with weapons to indicate their identity. The depiction of the face was portrayed in moon face style, which was highly praised during the time of the Ghaznavids [26]. The facial features are narrow eyes, a flat nose, small lips and a round face. The figures are arranged in a horizontal line, crowding towards a central sultan. The arrangement of such an allusion of marching and gathering may recall the glorious court life of the sultans. In the Shahnama, which is a Persian epic in the Islamic context dedicated to Sultan Mahmud by Firdawsi, the author records ceremonial activities such as banqueting, battling and hunting [27]. These activities were motifs for wall painting. There was an understated link between the visual imagery and socio-political order of the Ghaznavids' rule, exemplified by the historical and panegyric records.

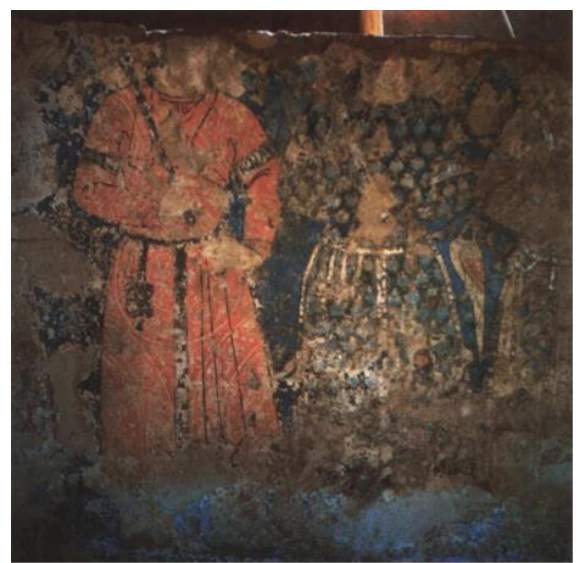

Fig 8. Mural figures 16 and 17. In Sourdel-Thomine, Janine., Lashkari Bazar: une résidence royale ghaznévide. Paris: C. Klincksieck, 1963-68. Planche 122.
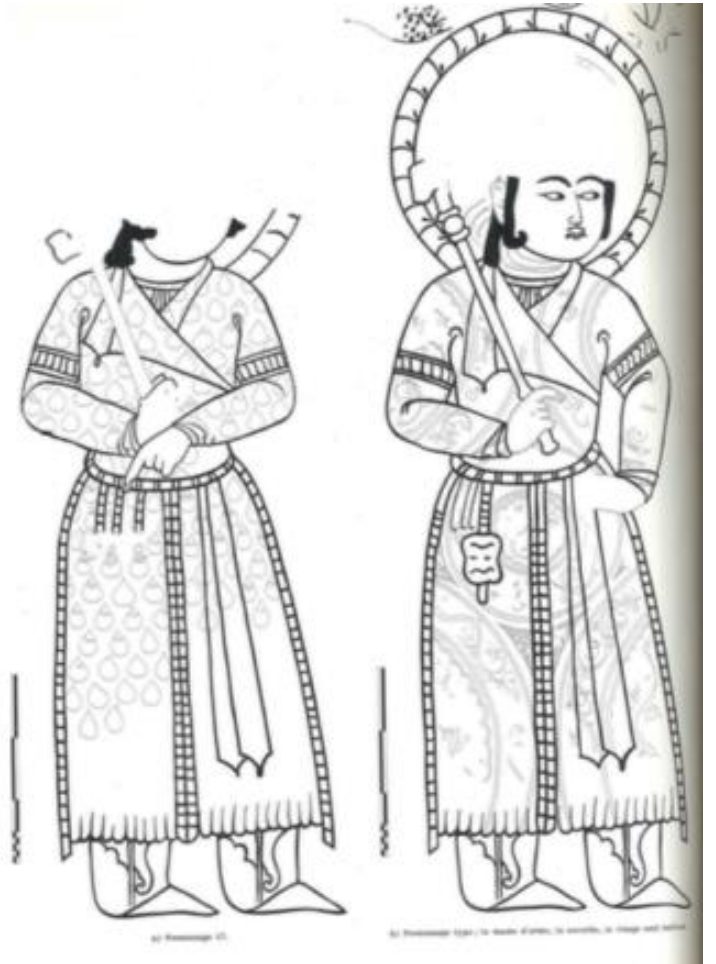

Fig 9. Painted figures in line drawings. In SourdelThomine, Janine., Lashkari Bazar: une résidence royale ghaznévide. Paris: C. Klincksieck, 1963-68. Planche 123.

\section{PANEGYRICS PROVIDES WRITTEN SOURCES TO INTERPRETATE LASHKARI-BAZAR FRESCO PAINTINGS IN THE AUDIENCE HALL}

Some scholars regarded medieval Islamic panegyrics as a form of flattery towards the king, and thus had no critical examination value. However, that is not the case. The Panegyrics provide written sources to the presentation of the court in terms of social and political order, which serves as a method of understanding medieval Islamic art such as palatial buildings and fresco paintings in Lashkari-Bazar.

\subsection{Panegyrics as court activity and record}

Firstly, literary production was an extensive court activity during the Ghaznavids' rule. While the royal court provided poets with space and occasion to participate in creational activities, the poets demonstrated presentations of the glorified court to the sultans in return [28]. The contents of the panegyrics thus were celebrations of the patrons' life, publicly and privately, including court activities, military campaigns, personal anniversaries and palatial constructions [29]. The relationship between the two was that of the Sultan being surrounded by intellectuals who could glorify and preserve their achievements, and the Sultan rewarding them as a part of the court ceremony.45 For example, 
through literature work, such as the legendary Shahnama, Sultan Mahmud' s legendary prestigious reputation has remained in history ever since.46 The presence of history in progress gave court authors first-hand material to be woven into history.

The process of turning scenes into historical writing is the second main feature of the Ghaznavids' panegyrics.47 Bayhaqi, a vigorous historical writer during Sultan Mas' ud' s reign, has stated several times in his book that he is an objective observer.48 He said:

" my purpose is rather to compose a foundation for history, and erect a noble edifice, such that it will continue to be spoken of till the end of time." (Meisami, 1993. 265) Bayhaqi devoted his effort into validating the ideal kingship through his books. His records of the rulers , virtue and gallantry in the discourse of court events have transferred power from predecessors and established its own governmental paradigm. The sociohistorical features and functions of the panegyrics shed light on the explanation of the palatial buildings and fresco paintings in Lashkari-Bazar.

\subsection{The just king}

\subsubsection{The monumentality}

Compared to saraparda tents and caravanserais where the Turks usually camped during the medieval Islamic period, the architectural project itself was monumental and ambitious. The axial plan is a connotation for the ceremony. Buildings with different functions, for example, baths, mosques, bazars and secondary residential houses, indicate that the construction was for both congregations and ceremonies. Audience halls, pavillions and gardens were royal reception sites, where the sultans were recorded in panegyrics, acted as just kings, according to Islamic and Persian political criteria.

\subsubsection{The metaphor of legitimisation}

The fresco paintings in the audience hall share a similar socio-political metaphor to legitimize the Sultan ' $s$ rule. First of all, the theme of these paintings is a presentation of the ceremony, such as the one in court panegyrics either celebrating an outdoor royal welcome parade by the townspeople or a palatial feast with musicians, scholars and authors. Secondly, the painting demonstrates an idealized version of a just king. Although the central figure was missing, the paradigmatic indication of a central people, crowded by a row of guards, exemplifying his virtue of being recognized by his followers.

In fact, according to Bayhaqi' s written records, Mas ' ud was an intellectual figure who was both skillful in Persian and Arabic and had talents in a variety of subjects, for example, he designed some palaces in Bust and other cities [32]. Bayhaqi also recorded the identification of the guards shown on the walls. They were the Sultan' s servicemen called ghulams, who were pages and cupbearers in the court when they were young, and later became soldiers [33]. Their beautiful appearances, dressed in delicate clothes with elegant faces, corresponded with the splendour of the royal ceremonies that took place in Mas'ud's palace, during which the fresco was depicted. The ceremony again implied the Ghaznavid Sultan' s rule.

\subsubsection{The unification of the past and the present}

The fresco was a unification of the legitimate past and glorified present. As analyzed in the previous passage, through political and cultural administration and activity, the sultans embodied the Persian past within the Islamic context to articulate their power in the present Islamic world [34]. The colour palette of using blue, red and gold might reinforce the lavishness of the Ghzanvids' gatherings. The magnificence of the court ceremony recalled parties held by the Iranian dihqans, who were cultivated nobleman known for their hostile entertainment and military strength. The Ghaznavid modeled themselves after the pride and cheerful character of these Persians as a demonstration of legitimacy.

\subsubsection{The permanent presence}

Moreover, the durability of fresco painting, such as the monumental existence of great literature at the time, was sought for eternity. As Firdausi wrote about Mahmud in his work: "Noble buildings are ruined by rain and by the heat of the sun. I have laid the foundations of a high palace of poetry that will not be damaged by wind and rain." (Tetley, 2008. 1) The ever-present marching queue to accompany a ruler in the middle of a royal setting was a metaphor for the sultans' dominance of power to break the linear timeline, and thus to enter eternity. The almost life-sized height and the black contour line of the figure emphasized a sense of permanent presence. This was a parallel to the court poets who were constantly in the process of making history.

\subsubsection{The tension between the ideal and the real}

Last but not least, the ever-lasting presentation of participants in the audience hall functioned similarly to the idealized imagery portrayed in court panegyrics. There was a constant shift in the identity of the subject and the object; when the Sultan resided inside the palace, the wall paintings were artistic objects to be admired, as characters in panegyric epics. While the Sultan was away, or dead, the life-size fresco figures would be subjects to guard the empty space, the characters dominate the narrative. Thus, there is an embodied tension between the idealized presentation and the real existence. The idealized representation has long been a topic discussed 
in relation to the panegyrics [35]. In conclusion, the audience hall wall paintings have substantial sociopolitical implications. With the assistance of the analytical method applied to the Ghaznavid panegyrics, one could view the frescoes as manifestations of the legitimacy of power and the Sultan' $\mathrm{s}$ attempts to continuous rule. The tension between recurrence of history and permanent rule had always been the struggle of Ghaznavid rulers, who never ceased to go on military expeditions.

\section{CONCLUSION}

The palatial complex of Lashkari-Bazar was conclusively a manifestation of the Ghaznavid court magnificence in terms of the sociopolitical order. The geographic location of the complex lay on the significant itinerancy route of the sultans. It served as a permanent accommodation as well as a transportation spot. The riverbank shares a palatial Islamic reference, while it also functioned as a Turkish military defense. The axial plan of the architectural structure exemplified the royal ceremonial processions, the activity of which was both shared by the Persian and the Islamic royal courts, as recorded in the panegyrics by court writers of the Ghaznavids' [36]. The conflation in temporal and spatial sense, to combine the Persian past with the Islamic present, was rendered in the function of the architectural structures and fresco paintings in the audience hall. The frescoes in the audience hall have an enduring presence in terms of the glorification of the Sultan. By presenting his image as a central authority among the carnivorous guards, the Sultan has been viewed as an idealized version of righteous rule. There has been a constant shift between object and subject, depending on the Sultan's presence, and an analogical tension between idealization and reality.

\section{BIBLIOGRAPHY}

Allen, Terry. "Notes on Bust." Iran, 26 (1988): 5568. doi:10.2307/4299800.

Allen, Terry. "Notes on Bust (Continued)." Iran 27 (1989): 57-66. doi:10.2307/4299817.

Allen, Terry. "Notes on Bust (Continued)." Iran 28 (1990): 23-30. doi:10.2307/4299832.

Bombaci, Alessio. "Summary Report on the Italian Archaeological Mission in Afghanistan. Introduction to the Excavations at Ghazni." East and West 10, no. 1/2 (1959): 3-22. www.jstor.org/stable/29754076.

Bosworth, C. E. "The Development of Persian Culture under the Early Ghaznavids." Iran 6 (1968): 3344. doi:10.2307/4299599.
Diba, Layla S. "Invested with Life: Wall Painting and Imagery before the Qajars." Iranian Studies 34, no. 1/4 (2001): 5-16. www.jstor.org/stable/4311419.

Ettinghausen, Richard., Grabar, Oleg., and Madina, Jenkins-Madina. Islamic art and architecture, 650-1250. P. 133-183. New Haven, Conn.; London: Yale University Press, 2001.

Hillenbrand, Robert. "The Architecture of the Ghaznavids and Ghurids," The Sultan's Turret: Studies in Persian and Turkish Culture, volume II, edited by Hillenbrand, Carole. Leiden: Brill, 2000.

Hillenbrand, Robert. Islamic Architecture, Form, Function and Meaning. Edinburgh: Edinburgh U.P., 1994.

Inaba, Minoru. "Sedentary Rulers on the Move: the Travels of the Early Ghaznavid Sultans," in TurkoMongol Rulers, Cities and City Life. Edited by DurandGuedy, David. P.75-98. Leiden [Netherlands]: Brill, 2013.

Meisami, J. S. "The Past in Service of the Present: Two Views of History in Medieval Persia." Poetics Today 14, no. 2 (1993): 247-75. doi:10.2307/1773119.

Meisami, Julie Scott. "Ghaznavid Panegyrics: Some Political Implications." Iran 28 (1990): 31-44. doi:10.2307/4299833.

Tetley, Gilles. The Ghaznavid and Seljuq Turks: poetry as a source for Iranian history. London; New York: Routledge, 2009.

\section{REFERENCES}

[1] Grabar, Oleg., et al., Islamic Art and Architecture, 650-1250. (New Haven, Conn.; London: Yale University Press, 2001), p.133-134.

[2] Bosworth, C. E. "The Development of Persian Culture under the Early Ghaznavids," Iran. 6 (1968), p.36-37.

[3] Meisami, Julie, Scott. "Ghaznavid Panegyrics: Some Political Implications," Iran. 28 (1990), p. 32-33.

[4] Bosworth, "The Development of Persian Culture under the Early Ghaznavids," p.37.

[5] Grabar, Oleg., et al. Islamic Art and Architecture, 650-1250, p.133.

[6] Bosworth, "The Development of Persian Culture under the Early Ghaznavids," p.37.

[7] ibid., For example, Farruki came from sistan, Unsuri from Balkh, Manuchihri from Damghan. See Boswroth, The Ghaznavids.

[8] Inaba, Minoru. "Sedentary Rulers on the Move: The Travels of the Early Ghaznavid Sultans," In Turko- 
Mongol Rulers, Cities and City Life. Edited by Durand-Guedy, David, (Leiden : Brill, 2013), p.7576.

[9] ibid., p.89-94. The Purpose of the Sultans' Travels.

[10] ibid., p.81. The 'figure-eight' road network.

[11] ibid., p.88-89.

[12] ibid., p.90-93

[13] Tetley, Gilles. The Ghaznavid and Seljuq Turks: Poetry as a source for Iranian history, (London; New York : Routledge, 2009), p.29. 17-20.

[14] Meisami, "Ghaznavid Panegyrics: Some Political Implications," p.32.; Tetley, The Ghaznavid and Seljuq Turks: poetry as a source for Iranian history, p.2.; Meisami, J. S, "The Past in Service of the Present: Two Views of History in Medieval Persia." Poetics Today 14, no. 2 (1993), p.250, 252, 263, 266.

[15] Bosworth, "The Development of Persian Culture under the Early Ghaznavids," p.39-40.; Meisami. "The Past in Service of the Present: Two Views of History in Medieval Persia," p.268.

[16] Hillenbrand, Robert, "The Architecture of the Ghaznavids and Ghurids," in The Sultan's Turret: Studies in Persian and Turkish Culture, volume II, edited by Hillenbrand, Carole, (Leiden: Brill, 2000), p.147.

[17] Hillenbrand, Robert, Islamic architecture: form, function and meaning, (Edinburgh: Edinburgh U.P., 1994), p.413.

[18] Allen, Terry. "Notes on Bust (Continued)." Iran, 27 (1989), p.57.

[19] Hillenbrand, Robert. "The Architecture of the Ghaznavids and Ghurids," p.382. This is a preIslamic tradition.

[20] Allen, Terry. "Notes on Bust." Iran, 26 (1988), p.6465.

[21] Meisami, "Ghaznavid Panegyrics: Some Political Implications" p.33-35.

[22] Allen, "Notes on Bust," p.61-62.

[23] Allen, "Notes on Bust (Continued)," p.57.

[24] ibid.,

[25] Hillenbrand, Islamic architecture: form, function and meaning, p.413.

[26] Bombaci, Alessio. "Summary Report on the Italian Archaeological Mission in Afghanistan. Introduction to the Excavations at Ghazni," East and West 10, no. 1/2 (1959): 3-22. p.13. See quotes from the Qabusname.

[27] Diba, Layla S. "Invested with Life: Wall Painting and Imagery before the Qajars," p.7.

[28] Meisami, "Ghaznavid Panegyrics: Some Political Implications.," p.32.

[29] Tetley, The Ghaznavid and Seljuq Turks: poetry as a source for Iranian history, p.2. 29. 32. 4

[30] ibid.

[31] Meisami, "The Past in Service of the Present: Two Views of History in Medieval Persia," p.265. 272 Also Tetley, The Ghaznavid and Seljuq Turks: poetry as a source for Iranian history, p.6, 20.

[32] Tetley, The Ghaznavid and Seljuq Turks: poetry as a source for Iranian history, p.33.

[33] ibid., p. 22.

[34] Bosworth, "The Development of Persian Culture under the Early Ghaznavids," p.36-37. 40

[35] Meisami, "Ghaznavid Panegyrics: Some Political Implications," p.1.

[36] Meisami, "The Past in Service of the Present: Two Views of History in Medieval Persia," p.272. 